\title{
Kendala Dalam Pelaksanaan Pembelian Terselubung (Undercover Buy ) Dalam Mengungkap Tindak Pidana Narkotika Oleh Penyidik Polri
}

\author{
Iqbal Taufik \\ Dosen Fakultas Hukum Universitas Pattimura \\ E-mail:Iqbal.taufik@fhukum.unpatti.ac.id,Iqbal.taufik87@gmail.com
}

\begin{abstract}
Investigators have an important role in uncovering the crime of narcotics, one way is to use the technique of covert purchase (undercover buy). In the execution of investigators often encounter obstacles, including: lack of number of factors necessary equipment, limited operating costs, investigators get terror and be a witness in the trial, difficulties in getting the informant, constraints determine the location of purchase veiled, and drug network that uses techniques mines. Thus, efforts should be made to overcome these obstacles, namely: improving human resources and reporting in order to be fulfilled, submit the plan to increase the number of articles of association, the investigator must be professional in performing their duties, to optimize the role of a suspect or a courier who had been caught, locate covert purchases away from the community, and by making use of article 86 paragraph (2).
\end{abstract}

Keywords : undercover buy, narcotics

\section{A. PENDAHULUAN.}

Pengertian Narkotika seperti yang tertuang dalam pasal 1 ayat (1) Undang-Undang Nomor 35 Tahun 2009 Tentang Narkotika bahwa narkotika adalah zat atau obat yang berasal dari tanaman atau bukan tanaman, baik sintetis maupun semisintetis yang dapat menyebabkan penurunan atau perubahan kesadaan, hilangnya rasa, mengurangisampai menghilangkan rasa nyeri dan dapat menimbulkan ketergantungan. Kejahatan narkotika dan obat-obatan terlarang telah bersifat transnasional yang dilakukan dengan modus operandi yang tinggi, teknologi yang canggih dan trend perkembangan kejahatan obat-obatan narkotika di Indonesia menunjukkan peningkatan yang sangat tajam. ${ }^{1}$ Hasil analisis Polri atas tingginya angka kejahatan tersebut salah satunya disebabkan oleh krisis ekonomi yang melanda hampir semua daerah. Dengan kejadian ini, para

\footnotetext{
Andi Hamzah \& RM. Surachman. (1994). Kejahatan Narkotika dan Psikotropika. Jakarta: Sinar Grafika, hlm. 5
} 
produsen, distributor dan konsumen memanfaatkan situasi ini untuk memperbesar dan mencari keuntungan dalam peredaran dan penyalahgunaan Narkoba. $^{2}$

Indonesia sekarang telah dijadikan tempat pemasaran. bahkan dijadikan sebagai produsen untuk jenis narkotika. Bila hal ini tidak ditanggulangi, akan dapat mengancam kehidupan bangsa dan negara. Hal ini dijadikan moment oleh Pemerintah bersama-sama Kepolisian terus melancarkan perang terhadap narkoba. Tercatat bahwa kasus narkotika dan psikotropika menyeret tersangka baik pria maupun wanita dari berbagai kalangan, dan barang bukti tindak pidana narkotika yang berhasil disita antara lain yaitu jenis narkotika seperti ganja, sabu-sabu, selain jenis-jenis narkotika tersebut juga ditemukan benda-benda atau alat yang ada pada tersangka seperti tas, uang, kantong plastik, timbangan, alat suntik, kendaraan dan benda-benda lain yang digunakan tersangka dalam melakukan tindak pidana narkotika.

Tindak pidana narkotika yang sering dilakukan dengan berbagai modus operandi. Dari kasus-kasus yang telah terungkap diketahui bahwa para pengedar tidak hanya mengedarkan dan menjual narkotika, tapi para pengedar memiliki peran ganda sebagai pemakai dan juga penjual. Dalam beberapa kasus pengedar yang tertangkap kebanyakan hanya memberikan keterangan bahwa mereka hanyalah orang suruhan, kurir atau perantara dalam suatu transaksi jual beli narkotika.

Permasalahan penyalahgunaan dan ketergantungan narkotika dan obat berbahaya (narkoba) mempunyai dimensi yang luas dan kompleks, baik dari sudut medis, maupun psikososial (ekonomi,

2 O.C Kaligis \& Associates. (2007). Narkoba dan Peradilannya di Indonesia, Cetakan ke-2, Alumni, Bandung, , hlm.vii. politik, sosial, budaya, kriminalitas, kerusuhan masal, dan lain sebagainya). ${ }^{3}$

Peredaran gelap narkotika banyak yang menggunakan sistem terputus, dimana antara anggota jaringan saling tidak mengenal, yaitu pemakai tidak mengenal pengedar, sedangkan pengedar yang satu tidak kenal dengan pengedar yang lain dan juga tidak mengenal siapa yang menjadi bandar narkotika.

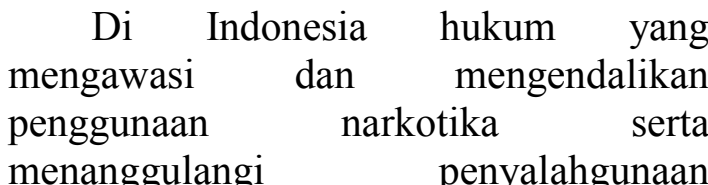
menanggulangi penyalahgunaan narkotika dan perawatan para korbannya dikenal dengan hukum narkotika. 4 Berbagai ketentuan yang mengatur mengenai penggunaan narkotika diawali dengan ditetapkannya Undang-Undang No 9 Tahun 1976. Kemudian seiring dengan perkembangannya kemudian pengaturan mengenai pengawasan penggunaan narkotika ini diganti dengan Undang-Undang No 22 Tahun 1997 tentang narkotika yang kemudian diperbaharui dan diganti lagi menjadi Undang-Undang Nomor 35 Tahun 2009 (selanjutnya disebut Undang-Undang Narkotika tahun 2009), karena undang-undang yang lama tersebut dianggap tidak cukup lagi dalam menangani peyebaran dan peredaran gelap narkotika.

Dalam Undang-Undang Narkotika tahun 2009 diatur mengenai proses penyidikan, penuntutan dan pemeriksaan di sidang pengadilan tindak pidana narkotika, tepatnya di Pasal 73 sampai dengan Pasal 103. Didalam setiap rangkaian penanganan kasus narkotika, proses penyidikan adalah proses yang

\footnotetext{
3 Mardani. 2008. Penyalahgunaan Narkoba, Dalam Perspektif Hukum Islam dan Hukum Pidana Nasional. Jakarta: Raja Grafindo Persada, hal.3.

4 Hari Sasangka. 2003. Narkotika dan Psikotropika dalam Hukum Pidana. Bandung Mandar Maju, hlm. 4.
} 
paling utama dalam memberantas penyalahgunaan narkotika. Hal ini dikarenakan seperti apa yang tertulis sebelumnya bahwa penyidikan merupakan suatu proses pengumpulan bukti-bukti yang dapat menentukan siapa tersangkanya, pada proses penyidikanlah dapat dikumpulan barang bukti yang dapat digunakan dalam membuktikan kejahatan dalam penggunaan narkotika. Selain itu pada tahap ini pulalah dapat diketahui status tersangka sebagai pemakai atau pengedar.

Undang-Undang Narkotika tahun 2009 tersebut didalamnya mengatur mengenai sanksi hukum dalam rangka pencegahan dan pemberantasan penyalahgunaan dan peredaran gelap narkotika dan prekursor narkotika. Maka, dengan undang-undang ini dibentuk Badan Narkotika Nasional yang selanjutnya disebut $\mathrm{BNN}$, seperti yang tertuang dalam Pasal 64 (1) badan inilah yang kemudian diberikan wewenang oleh pemerintah bersama dengan polri untuk mengungkap dan memberantas tindak pidana narkotika dan precursor narkotika yang sebelumnya tidak terdapat di dalam undang-undang lama serta didalamnya juga tertuang bahwa untuk obat-obatan jenis psikotropika golongan I dan golongan II telah dimasukan menjadi golongan narkotika seperti tertuang dalam Pasal 153 huruf (b) yang berbunyi, lampiran mengenai jenis psikotropika golongan I dan II sebagaimana tercantum dalam lampiran undang-undang nomor 5 tahun 1997 tentang psikotropika (Lembaran Negara Republik Indonesia tahun 1997 nomor 10), Tambahan Lembaga Negara 3 Republik Indonesia Nomor 3671 yang telah dipindahkan menjadi narkotika golongan I menurut undang-undang ini, dicabut dan dinyatakan tidak berlaku. Kemudian dengan dikeluarkanya undang-undang tersebut, maka penyidik baik dari Polri ataupun penyidik dari BNN diharapkan mampu membantu proses penyelesaian perkara terhadap seseorang atau lebih yang telah melakukan tindak pidana narkotika sekarang ini. Karena didalam undang-undang tentang narkotika ini telah diatur bagaimana penyidik bisa melakukan upaya-upaya yang digunakan untuk mengungkap kasus tindak pidana narkotika yang tertuang di dalam Undang-Undang Narkotika tahun 2009.

Aparat penegak hukum yang mempunyai peranan penting dalam menangani tindak pidana narkotika ialah penyidik. Dalam hal ini adalah Penyidik POLRI dan BNN, dimana penyidik diharapkan mampu membantu proses penyelesaian terhadap kasus tindak pidana narkotika, yang dimana penyidik memiliki berbagai cara untuk bisa mengungkap tindak kejahatan narkotika ini. Beberapa teknik penyelidikan itu mulai dari Observasi (peninjauan), Surveillance (pembuntutan), Undercover Agen (penyusupan agen), Undervocer Buy (pembelian terselubung), Controlled Planning (penyerahan yang dikendalikan), Phone Intercep (penyadapan telepon); dan Raid Planning Execution (rencana pelaksanaan penggerebekan) ${ }^{5}$

Berdasarkan hal-hal tersebut diatas, maka permasalahan yang diangkat dan dibahas dalam penulisan ini yaitu :

1. Kendala-kendala apa saja yang dihadapi penyidik terkait dengan pelaksanaan teknik pembelian terselubung (undercover buy)?

2. Upaya-upaya apa yang dilakukan oleh pihak penyidik dalam mengatasi kendala tersebut?

\section{B. PEMBAHASAN}

\begin{tabular}{cclr} 
Lembaga & \multicolumn{2}{l}{ kepolisian memiliki } \\
peranan yang & sangat besar dalam
\end{tabular}

${ }^{5}$ Syaefurrahman Al-Banjary, Hitam Putih Polisi dalam Mengungkap Jaringan Narkoba, PTIK Press, Jakarta, 2005, hlm. 29. 
kehidupan masyarakat ataupun dalam dimensi kenegaraan oleh kerenanya dengan ruang lingkup yang sangat luas di dalam tubuh kepolisian harus ada pemberian tugas yang jelas. Dalam pasal 13 Undang-Undang Nomor 2 Tahun 2002 tentang Kepolisian Republik Indonesia (selanjutnya disebut Undang-Undang Polri) disebutkan, bahwa tugas pokok kepolisian negara republik Indonesia adalah: (1) Memelihara keamanan dan ketertiban masyarakat, (2) Menegakan hukum, (3) Memberikan perlindungan, pengayoman dan pelayanan kepada masyarakat.

Dengan demikian adanya beberapa kewenangan POLRI untuk mencegah, menyidik dan memberantas masalah narkoba, lebih khususnya yaitu masalah narkotika. Kewenangan Polri untuk mencegah dan menanggulangi masalah narkotika tercantum dalam pasal 15 ayat (1) huruf c "POLRI berwenang untuk mencegah dan menanggulangi timbulnya penyakit masyarakat". Penyakit masyarakat yang dimaksud dalam hal ini adalah masalah penyalahgunaan narkotika.

Polri dalam hal menangani suatu kasus harus berpegang pada aturan hukum yang berlaku di Indonesia. Begitu pula dalam proses menangani suatu tindak pidana narkoba, polri harus melaksanakan aturan yang ada dalam Kitab Undang-undang Hukum Acara Pidana (KUHAP). Undercover Buy (pembelian terselubung) Pengertian undercover atau penyusupan adalah suatu operasi penyidikan yang sifatnya tertutup dan dirahasiakan, kegiatan ini disamarkan sedemikian rupa sehingga orang-orang yang melakukan dan segala kegiatanya tidak boleh menimbulkan kecurigaan pada orang disusupi. Tindakan pembelian terselubung (undercover buy) diatur dalam pasal 75 huruf J UU narkotika yang artinya penyidik narkotika dan prekursor narkotika berhak untuk melakukan atau bertindak langsung sebagai pembeli.

Pembelian Terselubung (undercover buy) sebagai sebuah teknik yang dilakukan oleh penyidik dalam tindak pidana narkotika dan precursor narkotika dapat kita lihat pengertianya dalam petunjuk lapangan No. Pol. Juklap/04/VIII/ 1983 disebutkan bahwa Pembelian terselubung (undercover buy) adalah suatu teknik khusus dalam penyelidikan kejahatan narkotika dan precursor narkotika, dimana seorang informan atau anggota polisi (dibawah selubung), bertindak sebagai pembeli dalam suatu transaksi gelap jual beli narkotika, dengan maksud pada saat terjadi hal tersebut si penjual atau perantara atau orang-orang yang berkaitan supply narkotika dan precursor narkotika dapat ditangkap beserta barang bukti apa adanya. ${ }^{6}$

Pelaksanaan pembelian terselubung ini dilakukan oleh penyidik Tindak Pidana Narkotika, akan tetapi tidak semua penyidik boleh melakukan pembelian terselubung ini. Pelaksanaan pembelian terselubung ini harus dilakukan oleh penyidik yang telah mendapatkan surat perintah/tugas dari pimpinan untuk melaksanakan pembelian terselubung. Dalam melakukan pembelian terselubung, penyidik dilindungi oleh Undang-Undang Narkotika. Selain Undang-Undang Narkotika perlidungan juga diberikan oleh KUHAP dan Undang-Udang Kepolisian.

Sedangkan peraturan internal kepolisian yang melindungi setiap tindakan yang dilakukan penyidik dalam pelaksanaan pembelian terselubung di lapangan adalah Surat Keputusan No.Pol SKep/1205/IX/2000/11 September 2000,

\footnotetext{
6 Petunjuk Lapangan, No. Pol. Juklap/04/VIII/1983, taktik dan teknik pembelian narkotika dan psikotropika.
} 
"tentang revisi Himpunan Juklak dan Juknis proses Penyidikan Tindak Pidana”.

Pelaksanaan pembelian terselubung tidak dapat dipisahkan dari beberapa tindak penyelidikan yang saling terkait. Tindakan penyelidikan tersebut antara lain observasi dan surveillance (pembuntutan). Setelah dilakukan beberapa tindakan penyelidikan tersebut barulah kemudian dapat dilaksanakan teknik penangkapan undercover buy (pembelian terselubung). Mengenai teknik tersebut akan dibahas satu persatu di bawah ini.

\section{Observasi (peninjauan);}

Berdasarkan petunjuk lapangan Kapolri Nomor Pol.Juklap/69/II/1993 dalam tindak pidana narkotika tidak dikenal adanya pelapor. Hal ini dikarenakan berdasarkan juklak tersebut dinyatakan bahwa korban dianggap sebagai pelaku. Bunyi dari ketentuan Juklap tersebut secara jelas adalah "Korban sebagai pelaku. Dimata polisi, dalam kejahatan narkotika tidak dikenal adanya korban. Seluruhnya mulai dari penanam, pembuat, pengedar dan pengguna/pemakai narkotika diperlakukan sebagai pelaku".

Berdasarkan bunyi ketentuan juklap tersebut dapat dilihat bahwa dalam tindak pidana narkotika tidak ada yang namanya saksi pelapor. Dalam tindak pidana narkotika yang dikenal adalah informan. Penyelidik dan penyidik bekerja berdasarkan adanya informasi dari informan. Informan disini bisa berasal dari masyarakat, Lembaga Swadaya Masyarakat atau bisa pula berasal dari sesama pemain (pengedar atau pemakai narkotika itu sendiri). Dengan adanya informasi tersebut kemudian dilakukan obesrvasi. Dari observasi tersebut dapat diketahui kondisi suatu tempat dan orang-orang yang ada di tempat tersebut.
Berdasarkan Surat Keputusan No.Pol SKep/1205/IX/2000/11 September 2000 tentang revisi himpunan Juklak dan Juknis Proses Penyidikan Tindak Pidana: buku petunjuk lapangan tentang penyelidikan, dikatakan bahwa proses obeservasi diawali dari pengamatan secara umum untuk mendapatkan gambaran umum/menyeluruh mengenai bagian-bagian/hal-hal yang istimewa secara terperinci atau khusus. Setelah dilakukan obeservasi awal kemudian dilanjutkan dengan obeservasi orang, observasi benda, obseravasi tempat dan obeservasi kejadian. Dari obeservasi inilah dapat diketahui bagaimana situasi lingkungan dari target operasi yang akan dilakukan penangkapan.

2. Surveillance (pembuntutan).

Surveillance adalah kegiatan pembututan secara sistematis terhadap orang, tempat dan benda. Biasanya surveillance dilakukan tehadap orang, sedangkan pembuntutan terhadap tempat/benda dilakukan karena ada hubungannya dengan orang yang diamati. Pembututan ini biasanya dilakukan dengan rahasia, terus-menerus dan kadang berselang untuk memperoleh informasi kegiatan dari sitarget operasi. Tujuan dari dilakukannya pembututan ini adalah untuk memperoleh bukti kejahatan, selain itu juga untuk melindungi petugas reserse (undercover agent) yang sedang melakukan penyamaran serta menguatkan kesaksian. Keberhasilan pelaksanaan pembututan ini tergantung dari kelihaian petugas dalam melakukan penyamaran. Dalam hal pembututan ini berhasil dilakukan maka penyidik dapat melakukan tindakan selanjutnya yaitu undercover buy. Dengan dilaksanakannya surveillance sesuai dengan prosedur yang tertulis di atas maka tingkat keberhasilan dari pelaksanaan 
surveillance tersebut pun akan lebih besar tercapai.

Pelaksanaan pembelian terselubung tentu saja dilakukan dengan cara terselubung. Dalam pelaksanaannya setelah dilakukan obeservasi dan surveillance, sebelum dilakukan penangkapan dengan cara pembelian terselubung biasanya dilakukan terlebih dahulu penyusupan agen (undercover agent). Hal ini dilakukan karena untuk mendapatkan suatu pelaku tindak pidana dalam tindak pidana narkotika tidak dapat dilakukan dengan cara-cara yang terbuka sehingga perlu penyamaran. Pelaksanaan penyusupan agen ini sangat berbahaya. Sehingga penyidik yang melaksanakannya benar-benar harus dipilih dan dipersiapkan sehingga memiliki kemampuan teknis untuk menyusup. Berikut adalah cara pelaksanaan undecover menurut buku petunjuk lapangan tentang penyelidikan yang telah direvisi oleh Surat Kapolri No SKep/1205/IX/2000, yaitu:

a. Melakukan pendekatan pada sasaran, yang telah ditentukan. Apabila ada hambatan Untuk pendekatan langsung, dapat melalui orang lain;

b. Setelah berhasil kontak dengan sasaran dilanjutkan dengan kegiatan-kegiatan untuk menumbuhkan kepercayaan dari saasaran, dengan menyebarluaskan cerita samaran di lingkungan sasaran. Pilih tempat tinggal, tempat hiburan dan tempat kerja yang dapat digunakan untuk mengamati kegiatan sasaran, baik langsung maupun tidak langsung.

c. Dalam hal petugas yang melaksanakan kegiatan undercover telah berada dan berhasil diterima dilingkungan sasaran, maka sebelum mengumpulkan bahan keterangan yang diperlukan, harus segera melakukan adaptasi dan bertindak hati-hati dengan cara:

1. Membatasi pembicaraan agar orang-orang yang ada disasaran lebih aktif berbicara.

2. Berusaha untuk mendengar semua hal yang dibicarakan oleh sasaran.

3. Gunakan kesempatan untuk mengadu domba antar anggota dari sasaran yang diselidiki.

4. Anggaplah orang-orang yang berada disasaran memiliki pengetahuan yang sederajat dengan petugas.

5. Perhatikan dengan seksama apa yang tampak disekitar tempat sasaran dan kegiatan-kegiatan apa yang tengah/akan berlangsung diingat tanpa mencatat.

6. Usahakan agar percakapan terus berlangsung, tanpa banyak pertanyaan, sebab pertanyaanpertanyaan tersebut dapat menimbulkan kecurigaan.

7. Jangan sampai terpengaruh terhadap hal-hal negatif yang dilakukan oleh orang-orang yang ada disasaran dengan memberikan alasan yang logis yang dapat diterima sasaran.

8. Penyelidik harus mampu dan menguasai tentang segala hal yang berkaitan dengan cover, baik cover name/cover job maupun cover story.

9. Jangan bersikap dan bertindak yang dapat menimbulkan kecurigaan dalam lingkungan orang-orang yang ada di sasaran.

10. Melakukan pengamatan secara cermat dan teliti yang 
diharapkan dapat memperoleh bahan keterangan lain.

11. Setiap kegiatan dilakukan sedemikian rupa sehingga kontak dengan pelindung/markas tetap dalam kerahasiaan tetap terjamin.

12. Komunikasai terhadap kawan supaya menggunakan tanda-tanda atau gerakan tubuh tertentu atau rahasia yang mudah disampaikan atau dimengerti.

Setelah melakukan transaksi dan tidak terdapat kecurigaan terhadap orang-orang terselubung maka, kemudian ditentukan saat yang tepat untuk melakukan operasi terselubung. Perencanaan yang baik akan menetukan operasi yang baik pula, sehingga usaha yang dilakukan sebelumnya akan dapat dinikmati keberhasilanya. Kegagalan dalam sebuah operasi narkotika dan psikotropika ini tidak hanya akan menggangu keamanan dan ketertiban di dalam masyarakat tetapi juga akan membahayakan orang-orang yang terlibat di dalam operasi tersebut.

Berdasarkan uraian di atas tentang proses yang harus dilakukan penyidik dalam menangani tindak pidana narkotika dan psikotropika dengan menggunakan tehnik pembelian terselubung (undercover buy) dapat dipahami dan dicermati bahwa dalam menangani suatu kasus tindak pidana jenis ini Polri mengalami berbagai kendala- kendala baik berupa kendala internal maupun eksternal.

Kendala-kendala internal yang muncul saat penyidik Polri menangani tindak pidana narkotika dan psikotropika yang dilakukan dengan tehnik pembelian terselubung (undercover buy )adalah sebagai berikut :
1. Kurangnya jumlah peralatan yang diperlukan

Kekurangan peralatan yang digunakan untuk melakukan penyelidikan maupun penyidikan dalam hal ini adalah untuk melakukan penyadapan. Tanpa adanya peralatan yang cukup maka dapat mempengaruhi kecepatan serta ketelitian penyidik dalam mengumpulkan alat bukti mengenai suatu tindak pidana narkotika. Misalnya dalam melakukan pembelian terselubung penyidik mengaku mengalami kesulitan dalam melakukan penyadapan yang nantinya akan berguna sebagai alat bukti mengingat bahwa alat bukti yang digunakan dalam mengungkap serta menangani tindak pidana narkotika yang menyatakan bahwa segala bentuk informasi baik elektronik maupun data rekaman atau informasi yang bisa dilihat maupun didengar maka akan bisa dijadikan alat bukti yang sah dalam persidangan untuk itu diperlukan penyadapan.

2. Terbatasnya biaya operasional

Proses penyelidikan dan penyidikan dengan tehnik pembelian terselubung (undercover buy), oleh penyidik dalam kasus narkotika dan prekursor narkotika memerlukan biaya operasional yang cukup tinggi jika dibandingkan dengan penyidikan dalam kejahatan konvensional. Dalam penyelidikan dan penyidikan tindak pidana narkotika dengan menggunakan tehnik pembelian terselubung (undercover buy), yang membutuhkan biaya operasional yang cukup besar, karena mengingat biaya tersebut juga meliputi biaya transportasi, biaya dalam melakukan tehnik pembelian terselubung (undercover buy), biaya penyadapan, dan lain-lain.

3. Penyidik mendapatkan teror dan menjadi saksi dalam persidangan. 
Walaupun anggota/agen penyusupan sudah merubah penampilan (dengan memakai anting, tato, dan berambut gondrong), namun mereka masih bisa dikenali dengan mudah oleh jaringan narkoba tersebut. Hal ini dikarenakan, setiap anggota/agen tersebut, setelah menangkap maka ia akan menjadi saksi dalam pemeriksaan di persidangan dan hanya dia yang mengetahui tentang proses penangkapan itu. Selain itu, anggota jaringan lain tersebut biasanya hadir dan berbaur di masyarakat untuk mengikuti persidangan kasus tersebut dan akan mengenali saksi-saksi khususnya dari anggota/agen yang dihadirkan.

Selain itu, kendala-kendala eksternal yang muncul saat menangani tindak pidana narkotika dan prekursor narkotika dengan tehnik pembelian terselubung (undercover buy), adalah sebagai berikut ;

\section{Kendala dalam mendapatkan} informan/spionase

Informan sendiri adalah orang yang memiliki informasi tentang suatu subyek yang ingin diketahui, dalam hal ini informan adalah yang berkaitan tentang tindak kejahatan narkotika. Informan ini orang yang dapat memberikan penjelasan yang detail, dan akurat menyangkut apa, siapa, dimana, kapan, bagaimana dan mengapa, dalam suatu kasus tindak pidana narkotika. Informan dalam mengungkap tindak pidana narkotika menempati kedudukan yang sangat penting, oleh karena itu polisi dalam mendapatkan informan ini sangat kesulitan. Tugas seorang informan sendiri adalah sebagai perantara polisi dalam mengungkap kasus narkotika. Dia adalah orang yang bertugas mengenalkan anggota polisi kepada tersangka. Tanpa informan ini, tidak ada informasi, dan tanpa informasi maka akan cukup sulit bagi polisi untuk mengungkap tindak pidana narkotika yang merupakan kejahatan jaringan yang terorganisasi. Dalam beberapa hal juga seorang informan ini adalah orang yang memiliki peran/berada dalam suatu jaringan narkotika, sehingga kepolisian bisa dengan mudah mendapatkan informasi tentang jaringan itu apabila sudah memiliki seorang informan. Seorang informan ini juga mungkin tidak memiliki kedudukan di dalam organisasi itu, namun memiliki akses yang besar untuk mengetahui informasi mengingat ia adalah anggota keluarga, pasangan, anak atau keponakan, atau mungkin asisten, bawahan pada umumnya, bahkan meskipun itu hanya pelayan/kurir.

2. Kendala menentukan lokasi pembelian terselubung.

Salah satu kendala yang harus dihadapi para penyidik adalah menentukan lokasi pembelian terselubung (undercover buy) karena penyidik harus mencari lokasi yang memungkinkan dilakukanya pengawasan terhadap gerak-gerik tersangka dan kemungkinan dilakukanya pengamanan terhadap pelaku undercover, uang transaksi dan menghindari tempat yang terlalu ramai dan terbuka, tidak banyak tempat yang bisa digunakan untuk melakukan operasi ini. Penyidik Polri harus terlebih dahulu mengamankan penduduk sekitar yang tidak terlibat dalam kasus itu karena operasi ini adalah operasi yang berbahaya.Waktu dan strategi untuk mengamati dan mempelajari tersangka yang disediakan dalam suatu operasi narkotika dan psikotropika juga haruslah cukup. Lebih baik menunda suatu rencana operasi narkotika dan psikotropika bilamana waktu tidak tepat dan membuat operasi yang dilakukan gagal. Gerakan tersangka disisni merupakan 
faktor utama yang harus diperhatikan oleh penyidik.

3. Jaringan narkoba menggunakan teknik ranjau.

Jaringan narkoba ini juga tidak tinggal diam dengan mencari tehnik-tehnik baru agar polisi sulit untuk menangkap jaringan mereka salah satunya adalah dengan tehnik ranjau. Tehnik ranjau yang dimaksud dalam hal ini pihak polisi dan kurir tidak saling bertemu secara langsung, karena baik bandar maupun kurir jaringan tersebut tidak ingin bertemu dengan polisi sehingga dalam melakukan pembelian terselubung polisi sering gagal. Tehnik ranjau ini dilakukan dengan cara setelah polisi melakukan pembelian terselubung dengan mengirim uang ke rekening bandar jaringan tersebut, maka bandar tersebut menghubungi kurir nya untuk melakukan tehnik ranjau ini. Kurir dalam hal ini meletakan narkoba tersebut ke suatu tempat yang kemudian setelah itu kurir menghubungi pembeli dan memberitahukan letak dimana dia meletakan barang tersebut. Cara lain yang digunakan yaitu narkoba dikirim ke pembeli via jasa pengiriman barang atau diletakkan di tempat sampah dilokasi tertentu kemudian menghubungi pembeli untuk mengambil. Hal tersebut dilakukan karena jaringan mereka takut untuk ditanggap dan waspada apabila yang melakukan pembelian tersebut adalah polisi.

Walaupun banyak kendala yang dihadapi Polri dalam menangani tindak pidana narkoba yang dilakukan dengan tehnik pembelian terselubung (undercover buy), akan tetapi Polri tetap mempunyai upaya-upaya untuk mengatasi kendala tersebut. Upaya-upaya dilakukan oleh penyidik untuk mengatasi kendala internal adalah sebagai berikut :
1. Upaya mengatasi kekurangan peralatan yang diperlukan, adalah dengan mengupayakan penyidik dalam pengoptimalisasian kinerja yaitu dengan melakukan upaya memaksimalkan Sumber Daya Manusia agar dapat menggunakan peralatan yang dibutuhkan dalam penyidikan secara maksimal.19 Dalam rangka peningkatan Sumber Daya Manusia penyidik, polri telah mengupayakan melalui peningkatan intensitas kegiatan-kegiatan pelatihan penyidikan dalam melakukan tehnik-tehnik yang digunakan penyidik dalam tindak pidana narkotika serta memaksimalkan daya kerja anggota penyidik polri Direktorat Reserse narkoba.

2. Upaya dalam mengatasi biaya operasional yang terbatas. Penyidikan suatu kasus narkoba yang dilakukan dengan tehnik pembelian terselubung (undercover buy) adalah dengan mengajukan rencana penambahan jumlah anggaran dengan harapan akan ditindaklanjuti langsung oleh bagian operasional.

3. Penyidik harus bersikap profesional. Penyidik yang yang akan melakukan tehnik pembelian terselubung (undercover buy) ini harus bersikap secara profesional dan hati-hati dalam menjalankan tugasnya, serta meminimalisir kesalahan atau bahkan jangan sampai melakukan kesalahan dalam tugas, karena hanya dengan sedikit kesalahan maka nyawa penyidik maupun anggota yang lain akan terancam bahaya atau operasi yang dilakukan akan gagal. Penyidik harus melakukannya sesuai dengan prosedur yang sudah ditetapkan oleh Polri agar tehindar dari bahaya, karena kesalahan yang dilakukanya apabila diketahui oleh anggota jaringan narkoba maka akan dimanfaatkan oleh jaringan tersebut, yang kemudian akan merugikan anggota serta penyidik itu 
sendiri. Profesionalisme adalah elemen terpenting dalam upaya untuk menanggulangi kendala-kendala yang ditimbulkan dalam melakukan pembelian terselubung (undercover buy) ini.

Jika upaya-upaya untuk mengatasi kendala internal sudah dilakukan oleh Polri, yang kedua adalah upaya represif, yaitu polri dalam mengatasi jika suatu tindak pidana narkotika yang dilakukan dengan teknik pembelian terselubung (undercover buy) sudah terjadi. Adapun upaya-upaya penyidik untuk mengatasi kendala-kendala eksternal sebagai berikut :

1. Mendapatkan informan dan mengoptimalkan peran tersangka; upaya yang dimaksudkan dalam mengoptimalkan peran informan disini yaitu dengan mengumpulkan informasi dengan menggunakan informan (mata-mata) dan melakukan pembelian terselubung dengan menggunakan kurir atau tersangka yang telah tertangkap. Informan ini biasanya berada di dalam lingkungan atau komunitas yang akrab dengan penggunaan narkoba. Informan yang ini tentu tidak melaporkan begitu saja ke polisi secara cuma-cuma, tentu ada yang diinginkan oleh informan tersebut biasanya polisi melakukannya dengan iming-iming uang.

2. Upaya dalam menentkan lokasi pembelian terselubung; upaya yang dilakukan penyidik polri dalam menentukan lokasi perlu diperhatikan hal sebagai berikut:

a. Lokasi harus memungkinkan dilakukannya pengawasan lawan dan kemungkinan dilakukannya pengamanan terhadap pelaku undercover dalam melakukan transaksi dan menghindari tempat yang terlalu ramai dan terbuka. b. Lokasi memungkinkan dipergunakan alat alat komunikasi dan deteksi baik untuk mengawasi lawan maupun untuk kepentingan komunikasi serta untuk koordinasi semua petugas.

c. Lokasi harus dikuasai sejak dini, sehingga memungkinkanya dilakukan usaha pengaman dan menghindari kontra penyelidikan pihak lawan.

Upaya yang dilakukan dalam mengatasi teknik ranjau; upaya yang dilakukan penyidik polri untuk mengatasi teknik ranjau ini dengan memanfaatkan kelemahan Teknik ranjau ini di mata hukum karena adanya Undang-Undang Narkotika tahun 2009 yaitu ada dalam pasal 86 ayat (2) tentang alat bukti yang sah.

\section{P E N U T U P}

Berdasarkan pembahasan yang telah dijelaskan, maka pada bagian akhir ini dikemukakan kesimpulan yakni Proses untuk mendukung pelaksanaan teknik pembelian terselubung (undercover buy) ini adalah dengan melakukan observasi (peninjauan), surveillance (pembuntutan), undercover agent (penyusupan agen), pengawasan terhadap pengiriman narkotika dan psikotropika (controlled dellivery), dan raid planning execution (rencana pelaksanaan penggerebekan).

Berdasarkan pada kesimpulan diatas , maka saran yang dapat dikemukakan sebagai berikut :

1. Baiknya perlu ditingkatkan lagi kinerja polri khususnya Direktorat Reserse Narkotika yang diimbangui dengan peningkatan sumber daya manusia dan meningkatkan biaya operasional untuk mendukung kasus narkotika yang ada agar penanganan terhadap tindak pidana narkotika dalam berjalan dengan lebih baik. 
2. Melengkapi perlengkapan dalam mendukung teknik-teknik yang dilakukan dalam mengungkap tindak pidana narkotika agar berjalan sesuai dengan prosedur dan tidak mengalami kegagalan.

3. Meningkatkan lagi penyuluhan/sosialisasi kepada masyarakat mengenai dampak negatif dari narkotika dan agar masyarakat juga ikut membantu member informasi apabila ada tindak pidana narkotika yang terjadi di masyarakat.

\section{DAFTAR PUSTAKA}

Hamzah, Andi \& Surachman, RM., 1994, Kejahatan Narkotika dan Psikotropika, Sinar Grafika, Jakarta.

Kaligis, O.C \& Associates, 2007, Narkoba dan Peradilannya Di Indonesia, Cetakan ke-2, Alumni Bandung.

Mardani, 2008, Penyalahgunaan Narkoba, Dalam Perspektif Hukum Islam dan Hukum Pidana Nasional, Raja Grafindo Persada, Jakarta.

Sasangka, Hari., 2003, Narkotika dan Psikotropika dalam Hukum Pidana, Mandar Maju, Bandung.

Syaefurrahman, Al-Banjary., 2005, Hitam Putih Polisi dalam Mengungkap Jaringan Narkoba,PTIK Press, Jakarta.

Undang- Undang Nomor 22 Tahun 1997 Tentang Narkotika

Undang- Undang Nomor 35 Tahun 2009 Tentang Narkotika
Undang-Undang Nomor 8 Tahun 1981 Tentang Kitab Undang-Undang Hukum Acara Pidana

Petunjuk Lapangan, No. Pol. Juklap/04/VIII/ 1983 Tentang Taktik Dan Teknik Pembelian Narkotika Dan Psikotropika 